\title{
Türkiye ve Dünya Hisse Senedi Piyasaları Arasındaki Getiri ve Oynaklık Yayılımlarının Ölçülmesi: Yayılma Endeksi Yaklaşımı
}

\author{
Zeliha CAN ERGÜN* Can KARABIYIK ${ }^{* *}$
}

\begin{abstract}
$\ddot{O} Z$
Çalı̧̧manın amacı gelişmiş ve gelişmekte olan piyasa ekonomilerinin yer aldiğ 19 ülkeye ait hisse senedi endekslerinde Ocak 2000 ve Haziran 2019 dönemi arasinda oynaklık ve getiri yayllmalarının incelenmesi ve bulguların Türk hisse senedi piyasası (Borsa İstanbul) özelinde yorumlanmasıdır. Çalışmada Diebold ve Yılmaz (2009) yayılma endeksi yöntemi kullanılmıs ve sonuç olarak $A B D$ ve Ingiltere'nin yayllım etkisinin en yüksek olduğu ülkeler olduğu bulunmuştur. Öte yandan, Türkiye'ye gelen ve Türkiye'den diğer ülkelere giden net yayllım etkisinin diğer ülkelere kıyasla yüksek seviyelerde olmadiğ l görülmektedir. Türkiye'de hisse senedi piyasası getirileri ve fiyat oynaklıkları çoğunlukla kendi iç şoklarından kaynaklanmaktadır. Son olarak, finansal stresin yüksek olduğu Mortgage krizi, Lehman Brothers iflast, Brexit referandumu gibi küresel olaylarda toplam yayılımın arttı̆̆ sonucuna ulaşılmışıtır.
\end{abstract}

Anahtar Kelimeler: Hisse Senedi Piyasası, Finansal Bulaşma, Oynaklık Yayılımı, Varyans Ayrıştırması, Finansal Kriz

JEL Sinıflandirmasl: E44, F36, G11, G15

\section{Return and Volatility Spillovers Between Turkish and World Equity Markets: Spillover Index Approach}

\begin{abstract}
The purpose of this study is to examine the volatility and return spillover effect in the stock indices of 19 developed and developing market economies during the period between January 2000 and June 2019, and it is also aimed to examine the findings specifically for Turkish stock exchange market (Borsa Istanbul). In the study, spillover index method of Diebold and Yllmaz (2009) is used and as a result, it is found that the USA and the UK have the highest spillover effect among other countries. On the other hand, the net effect spillover from Turkey to other and from other countries to Turkey are not at their high levels compared to others. In Turkey, return on equity markets and price volatility stems mainly from its internal shocks. Finally, it has been concluded that total spillover has increased in the crucial global events such as Mortgage crisis, Lehman Brothers bankruptcy, and Brexit referendum where financial stress is at its highest level.
\end{abstract}

Key Words: Equity Market, Financial Contagion, Volatility Spillover, Variance Decomposition, Financial Crisis

JEL Classification: E44, F36, G11, G15

\footnotetext{
* Arş. Gör. Dr., Adnan Menderes Üniversitesi Söke İşletme Fakültesi, Uluslararası Ticaret ve İşletmecilik Bölümü, zeliha.can@adu.edu.tr, ORCID Bilgisi: 0000-0003-3357-9859

*** Arş. Gör. Dr., Manisa Celal Bayar Üniversitesi, İktisadi ve İdari Bilimler Fakültesi, İktisat Bölümü, c_karabiyik@hotmail.com, ORCID Bilgisi: 0000-0002-7255-7946.
} 


\section{GíRiş}

Son yıllarda dünyada küreselleşmenin hızla gelişmesi birçok alanı olduğu gibi finansal piyasaları da önemli ölçüde etkisi altına almış ve piyasaların birbirlerine olan bağımlılığında artışa sebep olmuştur. $\mathrm{Bu}$ artan bağımlılığın etkisini, özellikle son yıllarda yaşanmış olan finansal krizlerde görmek mümkündür. Örneğin, 1997 yılında Asya'da başlayıp, sonrasında Rusya'ya ve takiben diğer ülkelere yayılan finansal krizde ve 2008 yılında Amerika'da başlayıp diğer ülkeleri etkisi altına alan küresel finansal krizde bu etki açıkça görülmektedir. Gamba-Santamaria, vd. (2017)'nin de belirttiği gibi son dönemde yaşanan uluslararası finansal krizler, ulusal politikaların ve finansal olayların etkilerinin sınır ötesi olduğunu açıç̧a göstermişler ve bu krizler volatilitelerin yayılma etkisi göstermesine sebep olmuşlardır.

Öte yandan, finansal piyasalar arasındaki entegrasyon uluslararası portföy çeşitlendirmesi açısından da önem arz etmektedir. Markowitz (1952) tarafindan geliştirilen Modern Portföy Teorisi'ne göre yatırımcılar portföylerini oluştururken çeşitlendirme yaparak risklerini en aza indirgeyip, üstlenilen bu riskten en yüksek getiriyi sağlamayı hedeflemektedirler. Yatırımcılar varlık çeşitlendirmesi yaparak sistematik olmayan, yani firmaya özgü, riskleri sıfira indirgeyebilirler. Ancak, sistematik riskler tüm piyasa için etkili olduğundan yatırımcılar bu tür piyasa risklerini varlık çeşitlendirmesi ile azaltamamaktadırlar (Büyükşalvarcı, 2010). Sistematik risk; faiz oranı riski, enflasyon riski ve politik risk gibi tüm pazarı etkileyen risklerden oluşmaktadır (Gallati, 2003: 24). Farklı ülke piyasaları arasındaki korelasyonun düşük olduğu varsayımına dayanarak, sistematik riskin ancak uluslararası portföy çeşitlendirmesi yoluyla azaltılabileceği düşünülmektedir (Sujan ve Govil, 2013). Fakat piyasaların küreselleşmesinden dolayı, sermaye piyasalarında türbülans olduğu dönemlerde ülkeler arasındaki finansal piyasa korelasyonunun artmasiyla birlikte sistematik risk seviyesi artmakta ve dolayısıyla çeşitlendirmenin faydaları azalmaktadır (Longin ve Solnik, 2001).

Finansal piyasaların gelişmesi, teknolojinin ilerlemesi ve rekabetin artmasıyla birlikte birbirlerine olan bağımlılığının artması "volatilite (oynaklık) yayılması" olarak adlandırılmaktadır (Çelik, vd., 2018). Volatilite yayılması, piyasa çalkantılarının bir ülkeden diğerine yayılmasını ifade eder ve hisse senedi fiyatları, döviz kurları veya sermaye akımlarındaki ortak hareketler yoluyla gözlemlenebilir (Dornbusch, vd., 2000). Diğer bir ifadeyle, volatilite yayılma olgusu, bir piyasadaki volatilitenin diğer piyasalardaki volatiliteleri tetiklediği durumlarda ortaya çıkar. Bu olgu, özellikle finansal olarak çalkantılı dönemlerde, uluslararası portföy çeşitlendirmesinin faydalarını azaltıcı bir etkisi olduğu için yatırımcılar açısından önemlidir (Yarovaya, Brzeszczyński ve Lau, 2016). Dolayısıyla, finansal riskten korunma, portföy yönetimi ve varlık tahsisi için volatilite yayılmalarının doğru bir şekilde tahmin edilmesi yatırımcılar için önemli bir yere sahiptir (Akça ve Öztürk, 2016).

$\mathrm{Bu}$ bilgiler doğrultusunda; çalışmanın amacı 19 ülkeye ait hisse senedi endekslerinde oynaklık ve getiri yayılmalarının Diebold ve Yılmaz (2009) yayılım endeksi metodolojisi kullanılarak incelenmesidir. Genel olarak, bu çalışmanın 
birkaç açıdan literatüre katkıda bulunacağı düşünülmektedir. İlk olarak, bu çalışma önceki çalışmalara göre daha geniş dönemi kapsamakta ve Ocak 2000 ve Haziran 2019 dönemleri arasındaki Mortgage krizi, Lehman Brothers'in iflası, Avrupa borç krizi ve Brexit referandumu gibi önemli ekonomik ve politik olayları içermektedir. İkincisi, analize dâhil edilen 19 ülke içerisinde yalnızca ABD ve İngiltere gibi gelişmiş ülkeler değil, Türkiye ve Brezilya gibi gelişmekte olan ülkeler de bulunmaktadır. Son olarak, yapılan analizler Türkiye özelinde incelenmiş ve yorumlanmıştır. $\mathrm{Bu}$ çalışmanın gelişmekte olan önemli pazarlardan biri olan Türkiye'deki yayılma etkisi hakkında görüş vererek, literatüre katkıda bulunacağ1 düşünülmektedir.

Çalışmanın geri kalan kısımlarında, ikinci bölüm ilgili literatürden bahsedecek, üçüncü bölüm yöntem ve veri hakkında bilgi sunacak, dördüncü bölümde analiz bulguları belirtilecek ve son bölümde sonuç kısmı yer alacaktır.

\section{LITERATÜR TARAMASI}

Literatürde, son zamanlarda, hisse senedi piyasaları arasındaki volatilite ve getiri yayılma etkisi çeşitli yöntemler kullanılarak; gelişmiş (bkz. Tsai, 2014; Gamba-Santamaria, vd., 2019) ve gelişmekte olan (bkz. Bayramoğlu ve Abasız, 2017; Çelik, Özdemir ve Gülbahar, 2018) ülke pazarlarında birçok araştırmacı tarafından incelenmiştir. Bazı çalışmalar ise gelişmiş ve gelişmekte olan ülkelerin hisse senedi piyasalarının birbirleri arasındaki volatilite yayılımını incelemişlerdir (bkz. Yarovaya vd., 2016; Gökbulut, 2017; Sahar ve Shah, 2017) Bu çalışmaların sonuçları, ele alınan ülkeler ve kullanılan yöntemler değiştikçe farklılık göstermektedir. Fakat sonuçlar incelendiğinde genel olarak yayılma etkisinin özellikle finansal kriz dönemlerinde arttığını görmek mümkündür (bkz. Akça ve Öztürk, 2016; Kırkulak Uludağ ve Ezzar, 2017; Hung, 2019). Yayılma etkisini incelemede çeşitli yöntemler kullanılmaktadır. Önceki çalışmalara bakıldığında, çoğunlukla VAR-EGARCH (bkz. Demirgil ve Gök, 2014; Bayramoğlu ve Abasız, 2017; Çelik, Özdemir ve Gülbahar, 2018), GARCH-BEKK (bkz. Beirne, vd., 2013; Kırkulak Uludağ ve Ezzat, 2017; Alfreedi, 2019), varyans nedensellik testi (bkz. Taşdemir ve Yalaman, 2010; Özdemir ve Vurur, 2019) gibi yöntemlerin kullanıldığı gözükmektedir.

Bu çalışmalardan farklı olarak; Diebold ve Yılmaz (2009) çalışmalarında basit bir niceliksel ölçüm önermişler ve bir yayılım endeksi (spillover index) oluşturmuşlardır. Daha sonra, bu endeksi kullanarak 19 ülke arasında, 1992-2007 yılları arasında, yayılma etkisinin varlığını incelemiş olup, getiri ve volatilite yayılımları arasında bir fark olup olmadığını araştırmışlardır. Sonuç olarak, getiri ve volatilite yayılmalarının dinamiğinde farklı davranışların olduğu bulunmuştur. $\mathrm{Bu}$ çalışmaya göre; getiri yayılmalarının hafifçe artan bir eğilim gösterdiği, ancak ani bir patlama olmadığı; volatilite yayılmalarının ise herhangi bir eğilim göstermediği, ancak belirgin ani patlamalar gösterdiği sonucuna ulaşılmıştır.

Diebold ve Yılmaz (2009)'ın yayılım endeksini oluşturmasının ardından, çeşitli araştırmacılar bu yöntemi kullanarak hisse senedi piyasalarında yayılımı incelemişlerdir. Bu çalışmalardan biri Tsai (2014) tarafından yapılmış olup, çalışmada 1994-2013 dönemi arasında ABD, İngiltere, Almanya, Japonya ve 
Fransa hisse senedi piyasalarının yayılım etkisi incelenmiştir. Sonuçlara göre, ABD hisse senedi piyasasının net yayılma etkisinin sıfırı aştığı üç dönem bulunmaktadır. Bunlar; 1997'den önceki dönem, 2000-2002 yılları arasındaki Dotcom balonu ve 2007-2008 yılları arasındaki Mortgage krizidir. Ayrıca, sonuçlara göre piyasada önemli bir korku olduğunda net yayılma etkisinin ABD'de güçlü olduğu gözükmektedir (Tsai, 2014). Chevallier, vd. (2018) ise 14 Pasifik Havzas1 ülkesinin hisse senedi piyasalarında 1992-2012 arası dönemde oynaklık yayılımını araştırmışlardır. Analiz sonuçları iki önemli bulguya ulaşmıştır. Birincisi; gelişmekte olan ASEAN piyasalarının birbirine bağımlılığı ABD şoklarına, Doğu Asya'nın gelişmiş ekonomilerine göre daha fazla maruz kalmaktadır. İkincisi; Pasifik Havzası ülkeleri arasındaki bağlantılar zaman içinde güçlenmiş ve bu yüzden bölgesel çeşitlendirme stratejilerinden yararlanma ihtimali azalmıştır (Chevallier, vd., 2018).

Bir diğger çalışma Gamba-Santamaria, vd. (2017) tarafindan ABD ve Latin Amerika ülkeleri için, 2003-2016 yıllarını kapsayan dönemde yapılmıştır. Bu çalışmada, Diebold ve Yılmaz (2009)'ın oluşturmuş olduğun oynaklık yayılım endeksi DCC-GARCH modeli kullanılarak genişletilmiş ve varlıklar arasındaki oynaklığın çok değişkenli ilişkilerini modellemek amaçlanmıştır. Sonuçlara göre; ele alınan dönemin büyük bir çoğunluğunda oynaklık yayılımının Brezilya'dan çıktığı ve genellikle Şile, Kolombiya ve Meksika'nın bu yayılımı aldıkları gözükmektedir. Ayrıca, yayılım endeksinin özellikle 2008 ve 2012 arasında önemli ölçüde yükseldiği ve ABD'den Latin Amerika ülkelerine şok geçişinin Lehman Brothers'ın iflas ettiği dönemlerde daha belirgin olduğu sonucuna ulaşılmıştır (Gamba-Santamaria, vd., 2017). Gamba-Santamaria, vd. (2019) bir diğer çalışmalarında; Avustralya, Kanada, Çin, Almanya, Japonya, İngiltere ve ABD hisse senedi piyasaları arasındaki yayılımı 1996-2017 dönemi arasında incelemişlerdir. Yapılan analiz sonuçlarına göre; toplam yayılım piyasa türbülansının yüksek olduğu dönemlerde daha fazladır. Buna ilave olarak yayılma genellikle gelişmiş ülke pazarlarından kaynaklanmaktadır ve oynaklık Çin piyasasına yayılmaktadır (Gamba-Santamaria, vd., 2019).

Bunların dişında, analiz edilen ülkeler arasında Türkiye'nin de bulunduğu çalışmalar bulunmaktadır. Bunlardan biri Akça ve Öztürk (2016) tarafından yapılmış olup, 2003-2014 yılları arası yapılan analize Türkiye haricinde ABD, İngiltere, Almanya, İspanya ve Yunanistan hisse senedi piyasaları dâhil edilmiştir. Sonuçlar, oynaklık yayılımının kriz dönemlerinde arttığını ve dolayısıyla bu dönemlerde portföy çeşitlendirme avantajının azaldığını göstermektedir (Akça ve Öztürk, 2016). Yarovaya vd. (2016) ise analizlerine Asya, Amerika, Avrupa ve Afrika'da bulunan 10 gelişmiş ve 11 gelişmekte olan ülke piyasalarını dâhil etmiş ve oynaklık yayılımı etkisini 2005-2014 dönemlerinde araştırmışlardır. Sonuç olarak, piyasaların bölgeler arası yayılmaya göre; yerel ve bölgeye özgü oynaklık şoklarına karşı daha duyarlı olduğu bulunmuştur (Yarovaya vd., 2016). Sahar ve Shah (2017) Müslüman çoğunluğunun bulunduğu Pakistan, Türkiye, Ürdün, Misır, Endonezya, Kuveyt, Lübnan, Fas ve Tunus ile ABD, Íngiltere ve Japonya ülkelerinin hisse senedi piyasalarında yayılım etkisini 1996-2016 arasındaki 20 
yıllık dönem için incelemişlerdir. Sonuçlar, ABD'nin grupta en etkili pazar olduğunu, Japonya'nın ise bazı ülkelerin oynaklığına katkıda bulunduğunu ve İngiltere'nin asgari bir etkisi olduğunu göstermektedir. Buna ek olarak, Müslüman ülkelerin oynaklığı arasında iki yönlü bir ilişki vardır (Sahar ve Shah, 2017). Son olarak, Polat (2018) 9 ülkenin (G-7, Norveç ve Türkiye) finansal sistemleri arasındaki yayılımını incelemiş ve önceki çalışmalar gibi ABD'nin ve İngiltere'nin en yüksek net finansal risk yayan ülkeler olduğu ve toplam yayılma endeksinin finansal kriz dönemlerinde yükseldiği sonucuna ulaşmıştır.

\section{YÖNTEM VE VERİ}

\section{A. Diebold ve Yılmaz Yayılma Endeksi Metodolojisi}

Bu çalışmada Diebold ve Yılmaz (2009) Yayılma Endeksi yöntemi kullanılmıştır. Yayılma endeksi yöntemi makro iktisadi değişkenler arasındaki şokların uluslararası yayılımının ölçülmesine olanak sağlamaktadır.

Yayılma Endeksi yöntemi varyans ayrıştırması ve VAR metodolojilerine dayanmaktadır. $\mathrm{Bu}$ yaklaşım; $\mathrm{i} \neq \mathrm{j}$ ve $\mathrm{i}=1, . ., \mathrm{N}$ koşulları geçerli olmak üzere, "i” ülkesinden " $\mathrm{j}$ " ülkesine gelen yayılıma ait tahmin hatası varyansı paylarının, her bir "i” ülkesi için ayrıştırılmasını ifade etmektedir.

Modeli basit bir şekilde açıklanabilmesi için Denklem 1'de kovaryans durağan, birinci derece ve iki değişkenli bir VAR modelini gösterilmiştir. Denklem 1 'de $\mathrm{x}_{\mathrm{t}}=\left(\mathrm{x}_{1 \mathrm{t}}, \mathrm{x}_{2 \mathrm{t}}\right)$ ve $\theta 2 \mathrm{x} 2$ parametre matrisi olmak üzere VAR modeli: $\mathrm{x}_{\mathrm{t}}=\theta_{\mathrm{i}} \mathrm{x}_{\mathrm{t}-\mathrm{i}}+\varepsilon_{\mathrm{t}}$

Denklem 1'de yer alan hata terimleri matrisi normal dağılıma sahiptir $\left[\varepsilon_{t} \sim\left(0, \sigma^{2}\right)\right]$ ve zaman endeksi " $t$ " $t=1,2, \ldots, T$ değerlerini almaktadır. Kovaryans durağanlık gereğince VAR modelinin hareketli ortalamalar gösterimi mevcuttur ve Denklem 2'de verilmiştir:

$\mathrm{x}_{\mathrm{t}}=\varphi(\mathrm{L}) \varepsilon_{\mathrm{t}}, \quad \varphi(\mathrm{L})=(\mathrm{I}-\theta \mathrm{L})^{-1} \quad$ olmak üzere

hareketli ortalamalar gösterimi farklı bir şekilde yeniden yazılacak olursa:

$\mathrm{x}_{\mathrm{t}}=\mathrm{A}(\mathrm{L}) \mathrm{u}_{\mathrm{t}} \quad$ elde edilir.

Denklem 3'te verilmiş olan parametreler aşağıdaki gibi formülize edilmektedir:

$\mathrm{A}(\mathrm{L})=\varphi(\mathrm{L}) \mathrm{Q}_{\mathrm{t}}^{-1}$

$\mathrm{u}_{\mathrm{t}}=\mathrm{Q}_{\mathrm{t}} \varepsilon_{\mathrm{t}}$

$\mathrm{I}=\mathrm{E}\left(\mathrm{u}_{\mathrm{t}} \mathrm{u}_{\mathrm{t}}^{\prime}\right)$

Denklem 4'te yer alan $\mathrm{Q}_{\mathrm{t}}^{-1}$ ifadesi $\varepsilon_{\mathrm{t}}$ 'nin kovaryans matrisininin alt üçgen Cholesky faktörünü göstermektedir.

Bir dönem ilerisinin tahminlendiği model (Wiener-Kolmogorov doğrusal en küçük karaler tahmini) göz önüne alınacak olursa, optimal tahminleme şu şekilde olacaktır:

$\mathrm{x}_{\mathrm{t}+1, \mathrm{t}}=\theta \mathrm{x}_{\mathrm{t}}$

Bir dönem ilerisinin tahminlendiği modelin hata vektörü Denklem 8'de gösterilmektedir:

$e_{t+1, t}=x_{t+1}-x_{t+1, t}=A_{0} u_{t+1}=\left[\begin{array}{ll}a_{0,11} & a_{0,12} \\ a_{0,21} & a_{0,22}\end{array}\right]\left[\begin{array}{l}u_{1, t+1} \\ u_{2, t+1}\end{array}\right]$

Denklem 8'e ait olan kovaryans matrisi ise,

$E\left(e_{t+1}, e_{t+1, t}^{\prime}\right)=A_{0} A_{0}^{\prime} \quad$ şeklinde elde edilir. 
Buradan, $\mathrm{x}_{1 \mathrm{t}}$ tahminine ait bir dönem ileri hata terimi varyansı $a_{0,11}^{2}+$ $a_{0,12}^{2}$ ve $x_{2 t}$ 'nin tahminine ait bir dönem ileri hata terimi varyansı ise $a_{0,21}^{2}+a_{0,22}^{2}$ şeklinde elde edilmektedir. Varyans ayrıştırması yöntemi kullanılarak tahmin hatası varyansları, her bir ülke için ayrıştırılabilmektedir. Böylelikle, $x_{1}$ ülkesi tahminlenmesindeki bir dönem ileri hata terimi varyansı, $\mathrm{x}_{1}$ ülkesinin iç şokları ve $\mathrm{x}_{2}$ ülkesinden $\mathrm{x}_{1}$ ülkesine yayılan edilebilmektedir. $\mathrm{x}_{\mathrm{i}}(\mathrm{i}=1,2$ olmak üzere) ülkesinin iç şokları "kendi varyans payı" şeklinde ifade edilmektedir. $x_{i}$ ülkesine $x_{j}(i, j=1,2$ ve $\mathrm{i} \neq \mathrm{j}$ ) ülkesinden yayılan şoklar ise "çapraz varyans payı" olarak ifade edilmektedir. Bu bölümde açıklanmış olan iki değişkene indirgenmiş basit örnekte, iki tip yayılma söz konusudur: $\mathrm{x}_{1 \mathrm{t}}$ ülkesinin iç şokları $x_{2 \mathrm{t}}$ ülkesinin tahmin hatası varyansını $a_{0,21}^{2}\left(\mathrm{x}_{1 \mathrm{t}}\right.$ ülkesindenden $\mathrm{x}_{2 \mathrm{t}}$ ülkesi yönlü yayılım) kadar etkilemekte ve $\mathrm{x}_{2 \mathrm{t}}$ ülkesinin iç şokları $\mathrm{x}_{1 \mathrm{t}}$ ülkesinin tahmin hatası varyansını $a_{0,12}^{2}\left(\mathrm{x}_{2 \mathrm{t}}\right.$ ülkesindenden $\mathrm{x}_{1 \mathrm{t}}$ ülkesi yönlü yayılma) kadar etkilemektedir. Toplam yayılım ise bu iki ifadenin toplanmasıyla " $a_{0,12}^{2}+a_{0,21}^{2}$ " şeklinde elde edilebilmektedir.

Toplam yayılma, kolaylikla okunabilen ve yorumlanabilen bir endekse dönüştürülebilmektedir. $\mathrm{Bu}$ amaçla toplam yayılma değerleri, tahmin hatası varyansına bağlı olarak ifade edilmelidir ve aşağıdaki gibi yazılmaktadır:

$a_{0,11}^{2}+a_{0,12}^{2}+a_{0,21}^{2}+a_{0,22}^{2}=\mathrm{iz}\left(\mathrm{A}_{0} \mathrm{~A}_{0}\right)$

Yayılma endeksi ise bu ifadenin yüzdelik değeridir. Yayılma endeksi aşağıdaki gibi elde edilmektedir:

$$
S=\frac{a_{0,12}^{2}+a_{0,21}^{2}}{i z\left(A_{0} A_{0}^{\prime}\right)} x 100
$$

Denklem 11 ile verilen basitleştirilmiş 2 değişkenli model P. derece $\mathrm{N}$ değişkenli bir VAR modeline genişletilebilmektedir:

$$
S=\frac{\sum_{i, j=1}^{N} a_{0, i j}^{2}}{i z\left(A_{0} A_{0}^{\prime}\right)} x 100 \quad, i \neq j
$$

Yayılma endeksinin $\mathrm{H}$ dönem ileri tahmin gerçekleştiren p. derece $\mathrm{N}$ değişkenli VAR modeline genişletilmiş genel hali Denklem 13'te gösterilmektedir:

$$
S=\frac{\sum_{h=0}^{H-1} \sum_{i, j=1}^{N} a_{h, i j}^{2}}{\sum_{h=0}^{H-1} i z\left(A_{0} A_{0}^{\prime}\right)} x 100
$$

\section{B. Veri}

Çalışmada ABD ve İngiltere gibi dünyanın en gelişmiş ekonomileri ile Türkiye ve Brezilya gibi gelişmekte olan piyasa ekonomilerinin yer aldığı 19 ülkeye ait hisse senedi endeksleri kullanılmıştır ${ }^{1}$. Kullanılan hisse senedi endeksleri yerel para cinsinden nominal değerlere sahiptir ve 17/01/2000-17/06/2019 dönemindeki 1014 gözlemi kapsamaktadır. Türkiye, Endonezya, Almanya ve Rusya endeks değerleri Investing ${ }^{2}$, diğer tüm endeks değerleri ise Yahoo Finance ${ }^{3}$ veri tabanlarından elde edilmiştir.

\footnotetext{
${ }^{1}$ Avustralya-S\&PASX 200, Brezilya-BVSP, Kanada-S\&P TSX, Çin-SSE, Danimarka-OMX, Fransa-CAC40, Endonezya-JKSE, Hindistan-SENSEX, İtalya-FTSE, Japonya-NIKKEI 225, Kore-KOSPİ, Meksika-IPC, RusyaMOEX, Suudi Arabistan-TASI, İspanya-IBEX 35, Türkiye-BIST 100, İngiltere-FTSE 100, ABD-S\&P 500.

${ }^{2}$ https://tr.investing.com/

${ }^{3}$ https://finance.yahoo.com/
} 
Haftalık nominal hisse senedi getirisi, nominal hisse senedi endeks değerlerinin logaritmik farkları alınarak elde edilmiştir. Haftalık reel hisse senedi getirisi ise tüketici fiyat endeksleri yardımıyla elde edilen enflasyon değerleri kullanılarak hesaplanmıştır. Aylık tüketici fiyat endeksinin haftalık tüketici fiyat endeksine dönüştürülmesi için Diebold ve Yilmaz (2009) tarafindan izlenen yöntem kullanılmıştır. $\mathrm{Bu}$ yönteme göre, haftalık enflasyon oranı $\pi_{t}$ 'nin ay boyunca sabit olduğu varsayılmaktadır ve haftalık enflasyon, aylık enflasyonun 1/4. kuvvetinin alınması ile hesaplanmaktadır. Haftalık reel getiri ise, $i_{t}$ nominal getiri olmak üzere, $\frac{\left(1+i_{t}\right)}{\left(1+\pi_{t}\right)}-1$ formülü ile elde edilmektedir. Avustralya'ya ait tüketici fiyat endeksi değerleri OECD, diğer tüm ülkelerin tüketici fiyat endeksi değerleri ise IMF'nin Uluslararası Finansal İstatistik (International Financial Statistics) veri tabanlarından elde edilmiştir.

Hisse senedi fiyat ve getiri oynaklıklarının hesaplanması için ise Diebold ve Yilmaz (2009) ile tutarlı olarak hisse senedi endeks değerlerinin gün içerisindeki en yüksek, en düşük, açılış ve kapanış fiyatlarının kullanıldığı ve ilk olarak Garman ve Klass (1980) tarafından ileri sürülen yöntem kullanılmıştır. Bu yönteme göre herhangi bir i piyasasındaki ve t haftasındaki oynaklık Denklem 14'te gösterilen formül ile hesaplanmaktadır:

$\tilde{\sigma}^{2}=0.511\left(H_{t}-L_{t}\right)^{2}-0.019\left[\left(C_{t}-O_{t}\right)\left(H_{t}+L_{t}-2 O_{t}\right)-2\left(H_{t}-O_{t}\right)\left(L_{t}-\right.\right.$ $\left.\left.O_{t}\right)\right]-0.383\left(C_{t}-O_{t}\right)^{2}$

Denklem 14 'te yer alan H, L, O ve C kısaltmaları sirasiyla hisse senedi endeksinin gün içindeki en yüksek, en düşük, açılış ve kapanış değerlerini göstermektedir. Veri setine ait tanımlayıcı istatistikler Tablo 1 ve Tablo 2'de gösterilmiştir.

\begin{tabular}{|c|c|c|c|c|c|c|c|c|c|c|}
\hline & AUS & BRA & CAN & CHN & DEN & ESP & FRA & GER & IDN & IND \\
\hline Ortalama & 0.524 & -0.192 & -0.048 & 0.001 & -0.008 & -0.041 & -0.035 & -0.031 & -0.147 & -0.099 \\
\hline Medyan & 0.210 & -0.204 & -0.168 & -0.156 & -0.147 & -0.176 & -0.155 & -0.152 & -0.201 & -0.212 \\
\hline Max & 9.568 & 0.303 & 0.503 & 0.567 & 0.413 & 0.606 & 0.499 & 0.501 & 0.401 & 0.581 \\
\hline Min & -0.562 & -0.304 & -0.258 & -0.295 & -0.270 & -0.278 & -0.253 & -0.257 & -0.361 & -0.346 \\
\hline Std. Sap. & 1.187 & 0.077 & 0.214 & 0.256 & 0.215 & 0.249 & 0.211 & 0.209 & 0.155 & 0.222 \\
\hline Çarpıklık & 2.785 & 4.449 & 0.975 & 0.571 & 0.469 & 1.054 & 0.834 & 0.858 & 1.984 & 1.477 \\
\hline Basıklık & 17.43 & 25.89 & 2.257 & 1.626 & 1.495 & 2.423 & 1.973 & 2.192 & 5.643 & 3.819 \\
\hline & ITA & JPN & KOR & MEX & RUS & SAU & TR & UK & USA & \\
\hline Ortalama & -0.090 & 0.028 & -0.049 & -0.130 & -0.203 & -0.045 & -0.166 & -0.082 & -0.059 & \\
\hline Medyan & -0.166 & -0.014 & -0.169 & -0.198 & -0.219 & -0.152 & -0.229 & -0.178 & -0.171 & \\
\hline Max & 0.377 & 0.473 & 0.450 & 0.423 & 0.378 & 0.437 & 0.566 & 0.432 & 0.661 & \\
\hline Min & -0.238 & -0.298 & -0.294 & -0.283 & -0.327 & -0.313 & -0.371 & -0.248 & -0.255 & \\
\hline Std. Sap. & 0.161 & 0.217 & 0.210 & 0.172 & 0.095 & 0.196 & 0.193 & 0.185 & 0.209 & \\
\hline Çarpıklık & 1.571 & 0.324 & 0.856 & 1.994 & 3.965 & 0.840 & 2.146 & 1.503 & 1.109 & \\
\hline Basıklık & 3.984 & 1.370 & 2.031 & 5.348 & 20.84 & 2.180 & 6.302 & 3.791 & 2.629 & \\
\hline
\end{tabular}

AUS, BRA, CAN, CHN, DEN, ESP, FRA, GER, IDN, IND, ITA, JPN, KOR, MEX, RUS, SAU, TR, UK ve USA kısaltmaları sırasıyla Avustralya, Brezilya, Kanada, Çin, Danimarka, İspanya, Fransa, Almanya, Endonezya, Hindistan, İtalya, Japonya, Güney Kore, Meksika, Rusya, Suudi Arabistan, Türkiye, İngiltere ve Amerika Birleşik Devletleri'ni ifade etmektedir. 

Oynaklık Yayılımlarının Ölçülmesi: Yayılma Endeksi Yaklaşımı

Tablo 1 incelendiğinde hisse senedi getirileri ortalama değerlerinin genel olarak negatif olduğu görülmektedir. Japonya ve Çin sıfira yakın olsa da pozitif değerler almışlardır. Avustralya örneklemde en yüksek ortalama getiri sağlayan piyasa konumundadır. Standart sapma değerleri ise Brezilya'da ve Rusya'da getiri dalgalanmalarının düşük düzeyde gerçekleştiğine işaret etmektedir.

Tablo 2: Oynaklık Tanımlayıcı İstatistikleri

\begin{tabular}{lllllllllll}
\hline & AUS & BRA & CAN & CHN & DEN & ESP & FRA & GER & IDN & IND \\
\hline Ortalama & 0.000 & 0.000 & 0.000 & 0.000 & 0.000 & 0.000 & 0.000 & 0.000 & 0.000 & 0.000 \\
Medyan & 0.000 & 0.000 & 0.000 & 0.000 & 0.000 & 0.000 & 0.000 & 0.000 & 0.000 & 0.000 \\
Max & 0.001 & 0.006 & 0.004 & 0.003 & 0.002 & 0.003 & 0.003 & 0.003 & 0.003 & 0.004 \\
Min & 0.000 & 0.000 & 0.000 & 0.000 & 0.000 & 0.000 & 0.000 & 0.000 & 0.000 & 0.000 \\
Std. Sap. & 0.000 & 0.000 & 0.000 & 0.000 & 0.000 & 0.000 & 0.000 & 0.000 & 0.000 & 0.000 \\
Çarpıklık & 6.793 & 7.815 & 9.496 & 5.104 & 5.519 & 5.046 & 6.059 & 5.393 & 6.305 & 7.379 \\
Basıklık & 62.67 & 88.64 & 121.8 & 42.61 & 49.23 & 44.25 & 57.58 & 42.09 & 59.11 & 77.96
\end{tabular}

\begin{tabular}{llllllllll}
\hline & ITA & JPN & KOR & MEX & RUS & SAU & TR & UK & USA \\
\hline Ortalama & 0.0001 & 0.0001 & 0.0002 & 0.0001 & 0.0003 & 0.0002 & 0.0004 & 0.0001 & 0.0001 \\
Medyan & 0.0001 & 0.0001 & 0.0001 & 0.0001 & 0.0001 & 0.0000 & 0.0002 & 0.0001 & 0.0000 \\
Max & 0.0027 & 0.0050 & 0.0043 & 0.0027 & 0.0127 & 0.0050 & 0.0133 & 0.0028 & 0.0038 \\
Min & 0.0000 & 0.0000 & 0.0000 & 0.0000 & 0.0000 & 0.0000 & 0.0000 & 0.0000 & 0.0000 \\
Std. Sap. & 0.0002 & 0.0003 & 0.0003 & 0.0002 & 0.0007 & 0.0004 & 0.0008 & 0.0002 & 0.0002 \\
Çarpıklık & 5.3529 & 10.128 & 6.8317 & 5.6776 & 10.3846 & 6.4996 & 10.364 & 6.6273 & 9.4613 \\
Basıklık & 45.163 & 143.18 & 68.184 & 51.726 & 140.252 & 56.676 & 154.72 & 64.173 & 126.50 \\
\hline
\end{tabular}

AUS, BRA, CAN, CHN, DEN, ESP, FRA, GER, IDN, IND, ITA, JPN, KOR, MEX, RUS, SAU, TR, UK ve USA kısaltmaları sırasıyla Avustralya, Brezilya, Kanada, Çin, Danimarka, İspanya, Fransa, Almanya, Endonezya, Hindistan, İtalya, Japonya, Güney Kore, Meksika, Rusya, Suudi Arabistan, Türkiye, İngiltere ve Amerika Birleşik Devletleri'ni ifade etmektedir.

Tablo 2'de yer alan oynaklık tanımlayıcı istatistiklerine göre, verisetinde yer alan ülkelerin tamamı ortalamada benzer düzeyde oynaklığa sahiptir. Ancak Rusya ve Türkiye'de gözlemlenen maksimum oynaklık değerleri göze çarpmaktadır. Buna göre Rusya ve Türkiye'de hesaplanmış olan oynaklık değerleri görece yüksek düzeylere çıkmaktadır. Bu değerler bu iki ülkenin standart sapma verilerine de yansımıştır.

\section{ANALIZ BULGULARI}

\section{A. Yayılım Tablosu}

Son yüzyılda küreselleşmenin artmasıyla özellikle kriz dönemlerinde, finansal piyasalar arasındaki etkileşim artmaktadır. Bunun sonucu olarak yatırımcılar için uluslararası portföy çeşitlendirmesi kararları önem kazanmaktadır, çünkü piyasalar arasındaki entegrasyonun yüksek olması portföy çeşitlendirmesinin faydalarını azaltıcı bir etkiye sahiptir (Yarovaya vd., 2016). Bu bağlamda; "volatilite (oynaklık) yayılması" kavramı piyasa çalkantılarının bir ülkeden diğerine yayılmasını ifade eder (Dornbusch, vd., 2000). Öte yandan bir 
piyasada hisse senedi getirisindeki artı̧̧ ekonomik büyümeyi destekleyerek toplam talebi uyarmakta ve pozitif bir talep şoku meydana getirebilmektedir. Bu şok ise o ekonominin ticaret partnerlerine yansiyabilmektedir. Milli gelirin artan fonksiyonu olan ithalatın artması, dış ticaret partneri ekonomilerde toplam talebin dolayısıyla da milli gelirin artmasına neden olacaktır. Bu mekanizmanın tersi de doğrudur. Bu bağlamda hisse senedi getirisi yayılımı ekonomik refahın/daralmanın yayılmasını ifade etmektedir. Yayılma endeksi yöntemiyle elde edilen getiri oynaklığı ve fiyat oynaklığı yayılımı bulgularını özetleyen yayılma tabloları, Tablo 3 ve Tablo 4'de sunulmaktadır.

Matris formunda gösterilmiş olan olan yayılma tablosunun satılları i ekonomisine gelen yayılımı (tahmin-hata varyansın1), sütunları ise $\mathrm{i}$ ekonomisinden diğer ekonomilere giden yayılımı ölçmektedir. Buna göre " $\mathrm{i}$ " ekonomisine " $\mathrm{j}$ " ekonomisinden gelen yayılım, yayılım tablosunda " $i$ " ekonomisinin yer aldığı satır ile "j”" ekonomisinin yer aldığı sütunun kesiş̧tiği noktada gösterilmektedir. Yayılma tablosunun en sağında yer alan sütun, satırlardaki ekonomilere gelen dış şokların toplam yüzdesini göstermektedir ve Yayılma endeksi değerleridir. Yayılma endeksi, "i” ekonomisinin bulunduğu satırdaki değerlerin kullanılmasıla oluşturulan bir oran yardımıyla elde edilmektedir. Bu oranın payı, yayılım tablosu matrisinin köşegen değerleri hariç olmak üzere "i” ekonomisinin yer aldığ satırdaki değerlerin toplanması ile elde edilmektedir. Oranın paydası ise, "i" ekonomisinin bulunduğu satırdaki değerlerin hepsinin toplanmasıyla elde edilmektedir. Bu değerler tabloda "diğerlerinden" sütununda görülebilmektedir. Yayılım tablosunun köşegen değerlerinde ise ekonomilerin kendilerine özgü, yayılımdan kaynaklanmayan iç şokları ölçülmektedir.

Herhangi bir "i" ekonomisinden diğer ekonomilere olan yayılımın tahminhata varyansı cinsinden ölçüsü ise, yayılım tablosunun alttan ikinci satırındaki "diğerlerine" bölümünde yer almaktadır. Diğerlerine değeri, "i" ekonomisinin iç şokları hariç tutularak hesaplanmaktadır. Veri setinde yer alan ekonomilerin kendi iç şokları ile yabancı piyasalara yayılan şokların toplamı ise "diğerlerine*" satırında gösterilmektedir.

Tablo 3'de yer alan "Getiri Yayılımı Tablosu" hisse senedi getirisi oynaklı̆̆ 1 yayılımı değerlerini göstermektedir. Bulgular getiri yayılımının en yüksek düzeyde olduğu ülkelerin dünyanın en büyük ekonomileri arasında yer alan $A B D$ ve İngiltere ekonomileri olduğunu göstermektedir. ABD kaynaklı net yayılım 101, İngiltere kaynaklı yayılım ise 117 olarak ölçülmüştür. Üçüncü en yüksek yayılım değeri ise 30 ile Almanya ekonomisine aittir. ABD ve İngiltere kaynaklı yayılım değerleri diğer ülke değerleri ile karşılaştırıldığında, ABD ve İngiltere'nin net finansal risk yayan ülkeler olduğu görülmektedir. Bu bulgular "ABD hapşırırsa dünya nezle olur" deyişini destekler niteliktedir. Bir başka deyişle sanayileşmiş ekonomiler birer lokomotif görevi görerek dünya ekonomisine yön vermektedirler. Benzer bulgu Polat (2018) tarafindan da elde edilmiştir ve bu etki 2008 küresel finansal krizinin ABD'nden yayılması ve İngiltere'de gerçekleşen Brexit referandumu gibi sebeplerle açıklanmıştır. 
Zeliha Can Ergün \& Can Karabıyık / Türkiye ve Dünya Hisse Senedi Piyasaları Arasındaki Getiri ve Oynaklık Yayılımlarının Ölçülmesi: Yayılma Endeksi Yaklaşımı

Tablo 3: Getiri Yayılımı Tablosu

USA UK GER FRA CHN JPN KOR CAN AUS DEN RUS SAU SP ITA IND IDN TR BRA MEX Diğerlerinden

\begin{tabular}{|c|c|c|c|c|c|c|c|c|c|c|c|c|c|c|c|c|c|c|c|c|}
\hline USA & 82.3 & 0.2 & 3.7 & 0.6 & 1.6 & 0.8 & 2.2 & 0.1 & 0.2 & 0.2 & 0.1 & 0 & 0.4 & 2.6 & 3.1 & 0.2 & 0.4 & 0.4 & 0.9 & 18 \\
\hline UK & 6.5 & 86.8 & 0.9 & 0.2 & 0.4 & 0.6 & 0.2 & 0.2 & 0.1 & 0.9 & 0.3 & 0 & 0.3 & 0.2 & 1.3 & 1.1 & 0.1 & 0 & 0.1 & 13 \\
\hline GER & 3.1 & 13 & 79.1 & 0.1 & 0 & 0.7 & 0.1 & 0.9 & 0.2 & 0 & 0 & 0.4 & 0 & 0.1 & 0.1 & 0.1 & 0.3 & 0.9 & 0.9 & 21 \\
\hline FRA & 6.3 & 35.7 & 2.2 & 49.1 & 0.4 & 0 & 0.3 & 1.6 & 0.2 & 0.8 & 0 & 0 & 0.1 & 0.1 & 0.3 & 0.4 & 1.7 & 0.6 & 0.2 & 51 \\
\hline CHN & 1.8 & 1.8 & 0.2 & 0.2 & 82.2 & 0.1 & 0 & 0.4 & 4.9 & 4.2 & 1.2 & 1.1 & 0 & 0.1 & 0.4 & 0.1 & 0.3 & 0.1 & 0.8 & 18 \\
\hline JPN & 2.9 & 6.7 & 3 & 0.7 & 0.2 & 81.2 & 0.4 & 0.6 & 0.5 & 0 & 0.1 & 0.1 & 0.7 & 0.1 & 0.7 & 0.6 & 0.1 & 0.1 & 1.1 & 19 \\
\hline KOR & 2.2 & 0.6 & 3.7 & 0.7 & 6.2 & 5.7 & 71.2 & 0.2 & 1.7 & 0.8 & 0.2 & 1.3 & 0.1 & 2.8 & 2.2 & 0.2 & 0.1 & 0 & 0.1 & 29 \\
\hline CAN & 37.3 & 0.8 & 0.8 & 0.1 & 1.1 & 0.1 & 0.5 & 55.4 & 0 & 0.3 & 0 & 0 & 0 & 2.1 & 0.6 & 0.4 & 0.1 & 0.1 & 0.1 & 45 \\
\hline AUS & 5.6 & 0.5 & 5.1 & 0.3 & 0.3 & 1.4 & 0 & 0.4 & 83 & 0 & 0.1 & 0 & 0.4 & 0.1 & 0 & 0 & 2 & 0.2 & 0.4 & 17 \\
\hline DEN & 14.8 & 11.9 & 0.3 & 0.4 & 2.9 & 0.5 & 1.6 & 3.5 & 0.4 & 59.7 & 0.2 & 0 & 0.5 & 1.9 & 0.7 & 0.3 & 0.1 & 0.1 & 0.3 & 40 \\
\hline RUS & 0.9 & 2.3 & 2 & 1 & 0.5 & 1.1 & 0.2 & 0.1 & 0.4 & 2.5 & 80.3 & 0.1 & 2.7 & 0.9 & 1.1 & 0.1 & 2.2 & 0.2 & 1.3 & 20 \\
\hline SAU & 1.2 & 1.8 & 1.2 & 0.3 & 0.2 & 0.1 & 0.4 & 0.2 & 0.5 & 0 & 0.3 & 89.6 & 0.3 & 0.2 & 0.4 & 0 & 1.3 & 1.1 & 0.9 & 10 \\
\hline SP & 6.9 & 33.5 & 0.3 & 5.7 & 0.8 & 2.2 & 1.4 & 0.9 & 1.1 & 1.9 & 0.8 & 0.7 & 39 & 0.4 & 0.9 & 0.7 & 1.7 & 0.5 & 0.4 & 61 \\
\hline ITA & 5 & 1.1 & 4.4 & 11.2 & 0.1 & 1 & 0.2 & 0 & 0.9 & 0.6 & 1.9 & 0.4 & 0.2 & 69.9 & 0.3 & 0.5 & 1.6 & 0.2 & 0.4 & 30 \\
\hline IND & 3.1 & 4.1 & 2 & 0.7 & 5.7 & 0.8 & 0.2 & 0 & 1.9 & 2 & 0.6 & 0.9 & 0.6 & 0.2 & 73.7 & 0.1 & 0.3 & 0.1 & 3.3 & 26 \\
\hline IDN & 0.5 & 1.5 & 0 & 0.1 & 0.4 & 1.8 & 2.7 & 0.1 & 1.2 & 0.5 & 0.2 & 0.2 & 0.9 & 2.1 & 0.7 & 86.9 & 0 & 0 & 0.3 & 13 \\
\hline TR & 2.1 & 0.6 & 0.4 & 0.1 & 1.1 & 1.4 & 0.3 & 1.2 & 0.4 & 2.1 & 0.7 & 0.1 & 1.6 & 1.3 & 0.4 & 0.1 & 73.3 & 0.5 & 12.2 & 27 \\
\hline BRA & 0.1 & 0.1 & 0.1 & 0.7 & 2 & 1.5 & 4.1 & 2.9 & 0.1 & 0.2 & 0.6 & 0.6 & 1.4 & 1.1 & 0.5 & 0.2 & 1 & 79.2 & 3.7 & 21 \\
\hline MEX & 1.1 & 0.8 & 0.2 & 0.2 & 1.2 & 3.2 & 1.5 & 0.9 & 2.1 & 0.2 & 0.8 & 1.5 & 0.1 & 0.5 & 0.1 & 0.9 & 2.9 & 0.8 & 81.3 & 19 \\
\hline Diğerlerine & 101 & 117 & 30 & 23 & 25 & 23 & 16 & 14 & 17 & 17 & 8 & 7 & 10 & 17 & 14 & 6 & 16 & 6 & 27 & 497 \\
\hline Diğerlerine* & 184 & 204 & 109 & 72 & 107 & 104 & 88 & 70 & 100 & 77 & 88 & 97 & 49 & 87 & 87 & 93 & 90 & 85 & 109 & $26.20 \%$ \\
\hline
\end{tabular}

Tablo 3 Türkiye ekonomisi özelinde incelendiğinde ise, Türkiye ekonomisine gelen net getiri yayılımının en büyük kaynaklarının \%2,1 ile ABD, $\% 2,1$ ile Danimarka, \%1,6 ile İspanya ve \%12,2 ile Meksika ekonomileri olduğu görülmektedir. Toplam yayılımda en büyük paya sahip olan ABD ve İngiltere'den Türkiye'ye gelen net getiri yayılımının ise \%2,1 ve \%0,6 ile sinırlı kaldığ 1 görülmektedir. Elde edilen bulgulara göre Türkiye'ye gelen ve Türkiye'den diğer ülkelere giden net yayılım etkisi yüksek seviyelerde değildir. Bu bulgu Polat (2018) ile tutarlıdır. Polat (2018) G-7 ülkeleri için gerçekleştirdiği çalışmada Türkiye'ye gelen ve Türkiye'den yayılan net etkinin, diğer ülkelere kıyasla düşük olduğunu saptamıştır. Türkiye'ye gelen net yayılım etkisinin yüksek düzeylerde olmaması, Türkiye ekonomisinin küresel şoklardan etkilenme düzeyinin yüksek olmadığını göstermektedir. Örneğin 2008 küresel finansal krizinin Türkiye'deki etkilerinin görece düşük düzeyde olması, bir başka deyişle krizin Türkiye'yi teğet geçtiği argümanı bu iddiayı destekler niteliktedir. Öte yandan Türkiye'den yayılan net etkinin düşük düzeyde olması, Türkiye'nin küresel ekonomiyi etkileyecek büyüklükte şoklar üretemediği anlamına gelmektedir. Bunlara ilave olarak Türkiye hisse senedi piyasası getirilerinde meydana gelen oynaklığın \%73,3'ünün, Türkiye'nin kendi iç şoklarından kaynaklandığı saptanmıştır.

Tablo 3, verisetindeki ülkelerin genelinin Türkiye ile paralel olarak küresel şoklardan etkilenme düzeyinin yüksek olmadığını göstermektedir. Verisetinde yer 
alan Hindistan, Endonezya, Brezilya gibi gelişen piyasa ekonomilerindeki hisse senedi getirsi yayılımı, kaynak ülkeler; coğrafi, kültürel ve ekonomik sebeplerle farklılık gösterse de genel olarak Türkiye ile benzer yapıdadır. Bu ülkelerde yaşanan hisse senedi getiri şokların yaklaşık \%15 ila \%30 luk kısmının dış şoklardan kaynaklandığını göstermektedir. Ancak gelişmiş ülkelerden Fransa, Danimarka, Kanada ve İspanya'nın görece yüksek düzeyde dış şoka maruz kaldığı da gözlemlenmektedir.

Tablo 4'de yer alan "Oynaklık Yayılımı Tablosu" hisse senedi fiyat oynaklığı yayılımı değerlerini göstermektedir. Analiz bulguları getiri oynaklığ yayılım tablosu değerleri ile benzer şekilde, fiyat oynaklık yayılımının en yüksek düzeyde olduğu ülkelerin ABD ve İngiltere ekonomileri olduğunu göstermektedir. ABD'nin toplam oynaklık yayılımı üzerindeki payının ise, diğer ülkeler ile kıyaslanamayacak düzeyde yüksek olduğu görülmektedir. Oynaklık yayılımı tablosunun "Diğerlerine" satırındaki net yayılım değerlerinden görülebileceği üzere, ABD kaynaklı oynaklık yayılımı toplam yayılımın hemen hemen yarıs1 (478/1076) kadardır. Bu değer ise ABD’nde gerçekleşen şokların küresel ekonomi üzerindeki etkisini vurgulamaktadır.

Tablo 4: Oynaklık Yayılımı Tablosu

USA UK GER FRA CHN JPN KOR CAN AUS DEN RUS SAU SP ITA IND IDN TR BRA MEX Diğerlerinden

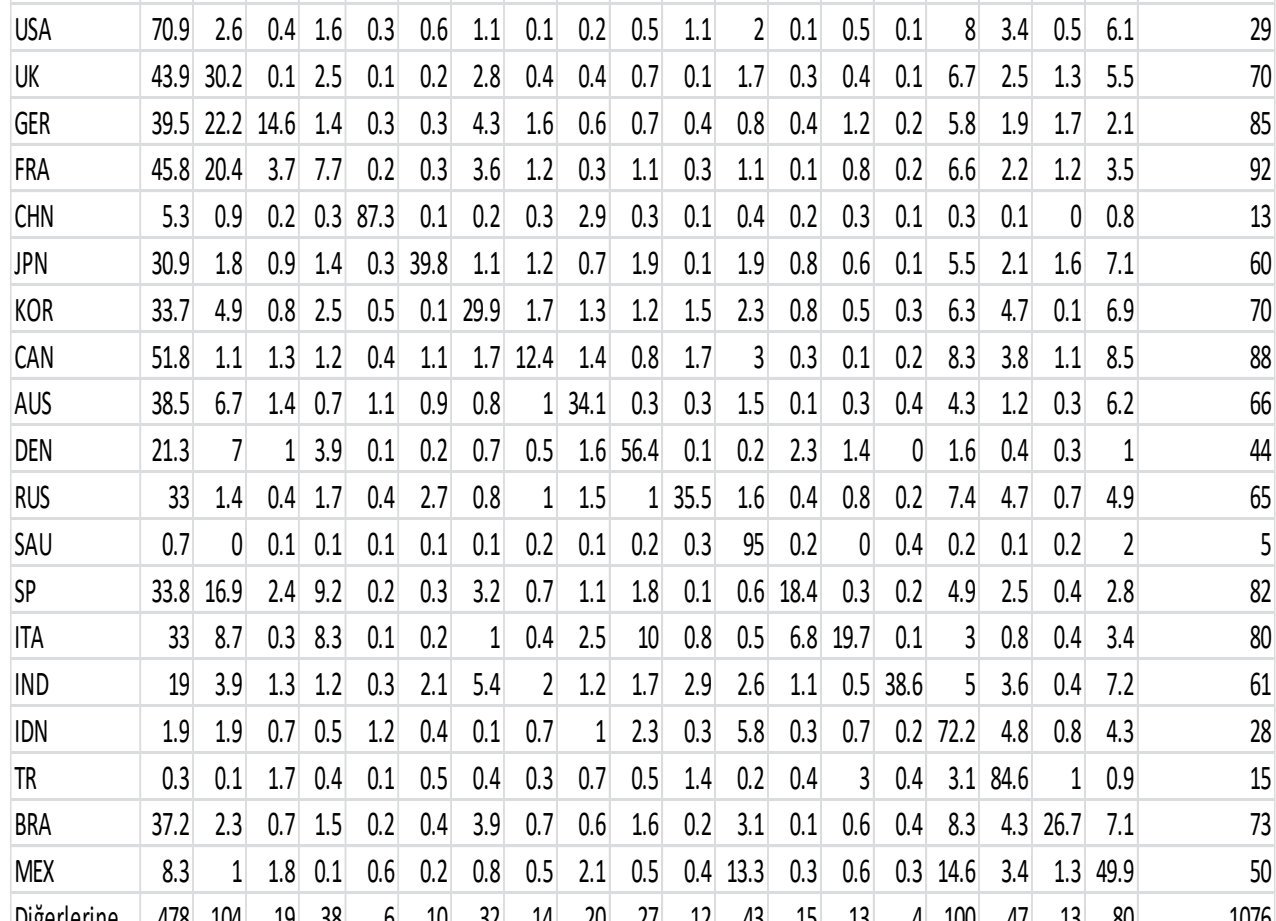

$\begin{array}{llllllllllllllllllllll}\text { Digerlerine } & 478 & 104 & 19 & 38 & 6 & 10 & 32 & 14 & 20 & 27 & 12 & 43 & 15 & 13 & 4 & 100 & 47 & 13 & 80 & 1076\end{array}$ $\begin{array}{lllllllllllllllllllll}\text { Diğerlerine* }^{549} & 134 & 34 & 46 & 94 & 50 & 62 & 27 & 54 & 83 & 48 & 138 & 33 & 32 & 42 & 172 & 131 & 40 & 130 & 56.60 \%\end{array}$ AUS, BRA, CAN, CHN, DEN, ESP, FRA, GER, IDN, IND, ITA, JPN, KOR, MEX, RUS, SAU, TR, UK ve USA kısaltmaları sırasıyla Avustralya, Brezilya, Kanada, Çin, Danimarka, İspanya, Fransa, Almanya, Endonezya, Hindistan, İtalya, Japonya, Güney Kore, Meksika, Rusya, Suudi Arabistan, Türkiye, İngiltere ve Amerika Birleşik Devletleri'ni ifade etmektedir. 
Oynaklık yayılımı değerleri, getiri yayılımı değerlerinden farklı olarak, ABD’den İngiltere $(\% 43,9)$, Almanya $(\% 39,5)$, Fransa $(\% 45,8)$, Japonya $(\% 30,9)$, Kore $(\% 33,7)$, Kanada $(\% 51,8)$, Avustralya $(\% 38,5)$, İspanya $(\% 33,8)$ ve İtalya (\%33) gibi gelişmiş ülkelere yüksek düzeyde oynaklık yayılımı olduğunu göstermektedir. Öte yandan ABD'den Türkiye'ye gelen net oynaklık yayılımı \%0,3 düzeyindedir ve ABD'den yayılan en düşük oynaklık yayılımı değeridir. Bu değer, özellikle diğer gelişen piyasa ekonomileri ile karşılaştırıldığında çarpıcıdır. Örneğin ABD'den Brezilya'ya yayılan oynaklık şoku Türkiye'nin on katından yüksek değer almaktadır. Türkiye'de hisse senedi fiyat oynaklığının \%84,6'sının Türkiye'nin kendi iç dinamiklerinden kaynaklandığı görülmektedir. Örneklemde yer alan ülkelerden Türkiye'ye ortalama \%1 civarında net oynaklık yayılımı gelmektedir. Bu bulgular BIST 100 endeksi değerlerinin diş etkenlerden etkilenme düzeyinin oldukça düşük olduğunu göstermektedir.

Yayılım tablosunda görülen bir diğer önemli bulgu ise, ekonomiler arasındaki yayılım endeksi değerlerini tek bir değere indirgeyen "Toplam Yayılma Endeksi” değeridir. Bu değer yayılım tablosunun sağ alt köşesinde yer almaktadır. Toplam yayılma endeksi değeri "diğerlerinden" sütunu toplamının, "diğerlerine*" satırı toplamına bölünüp 100 ile çarpılması sonucu elde edilmektedir. Bu değer dış şokların, toplam şoklar içerisindeki payını yüzde cinsinden vermektedir. Bir başka deyişle toplam yayılımın büyüklüğünün ölçüsüdür. Bu çalışma sonucunda elde edilen yayılım tablosu sonuçlarına göre, hisse senedi getirisi oynaklığının \%26,2'si yayılım etkisinden kaynaklanmaktadır. Aynı değer hisse senedi fiyatı oynaklık yayılımı için \%56,60 olarak hesaplanmıştır.

\section{B. Dinamik Kayan Örneklem Analizi}

Diebold ve Y1lmaz (2009) yayılım endeksi metodolojisi ülkeler ve piyasalar arasındaki yayılım etkisinin yüzdesel olarak elde edilebilmesine olanak sağlamaktadır. Bu yöntemin bir başka avantajı ise, yayılımın dinamik analizinin yapılabilmesidir. Toplam yayılımın zaman boyutundaki değişimi kayan örneklem (rolling-sample) analizi ile incelenmektedir. Kayan örneklem analizi ile Şekil 1'de "Toplam Getiri Yayılımı" Şekil 2'de ise "Toplam Oynaklık Yayılımı" grafikleri gösterilmiştir. Bu grafikler kayan pencere grafiği olarak adlandırılmaktadır.

Toplam yayılım finansal stresin yüksek olduğu dönemlerde artmaktadır (Cronin, 2014; Diebold \& Yilmaz, 2009, 2012; Polat, 2018; Zhou vd., 2012). Bu nedenle finansal stresin yükseldiği Lehman Brothers iflası, Avrupa borç krizi vb. küresel finansal olaylar derlenerek, toplam yayılım üzerindeki etkilerinin gözlemlenebilmesi amacıyla Şekil 1 ve Şekil 2 üzerinde işaretlenmiştir. Buna ilave olarak küresel ekonomiyi etkileyebilen toplumsal ve siyasi olaylar da şekillerde gösterilmiştir.

Şekil 1 kayan pencere grafiğine göre toplam getiri yayılımı 2005 yılının ikinci çeyreği itibariyle yükselmeye başlamıştır. Bu tarihte; Güney Kore, Rusya, Çin, Hindistan ve Japonya gibi gelişmiş ve gelişmekte olan ülkelerdeki politikacılar, merkez bankası rezervlerini ABD doları haricindeki para birimleri ile çeşitlendireceklerine dair açıklamalarda bulunmuşlardır ve Mart 2005 ABD doları krizi başlamıştır. İzleyen dönemde FED tarafından verilen faiz artırımı 
sinyalleriyle, Mayıs-Haziran 2006 döneminde gelişen piyasalardan yüklü sermaye çıkışı yaşanmıştır.

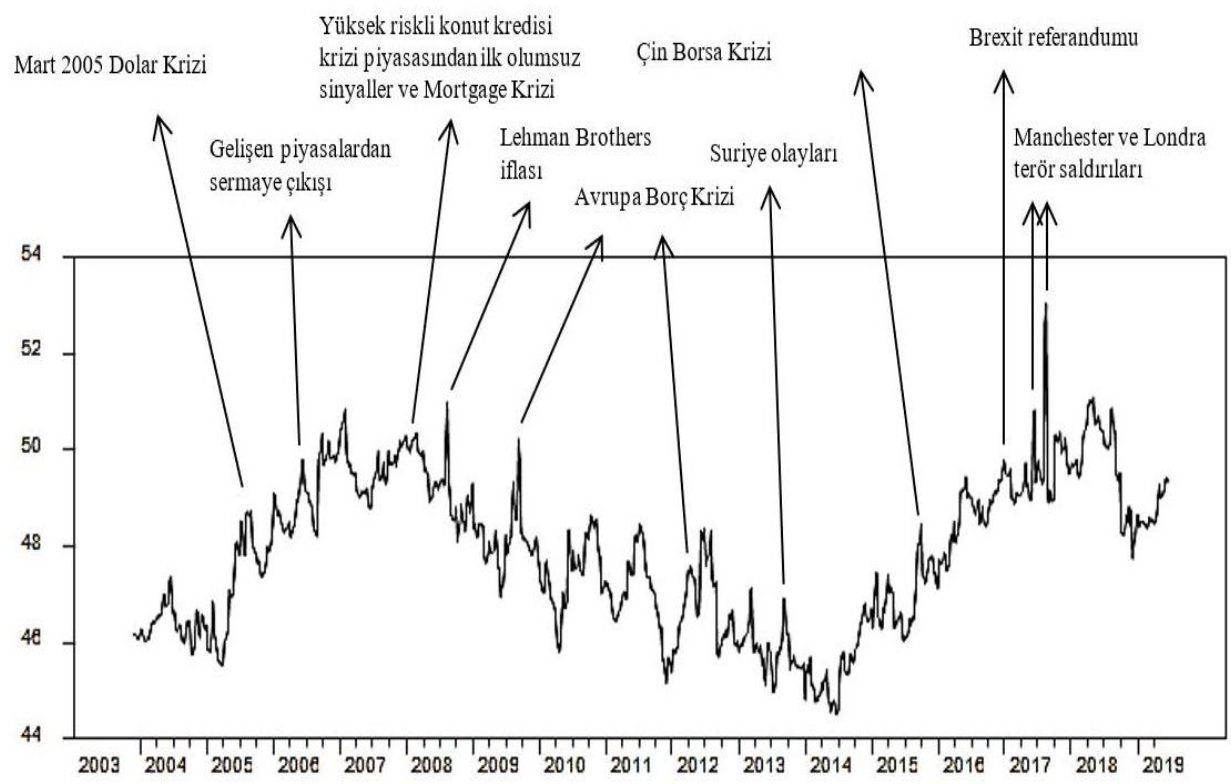

Şekil 1: Toplam Getiri Yaylımı

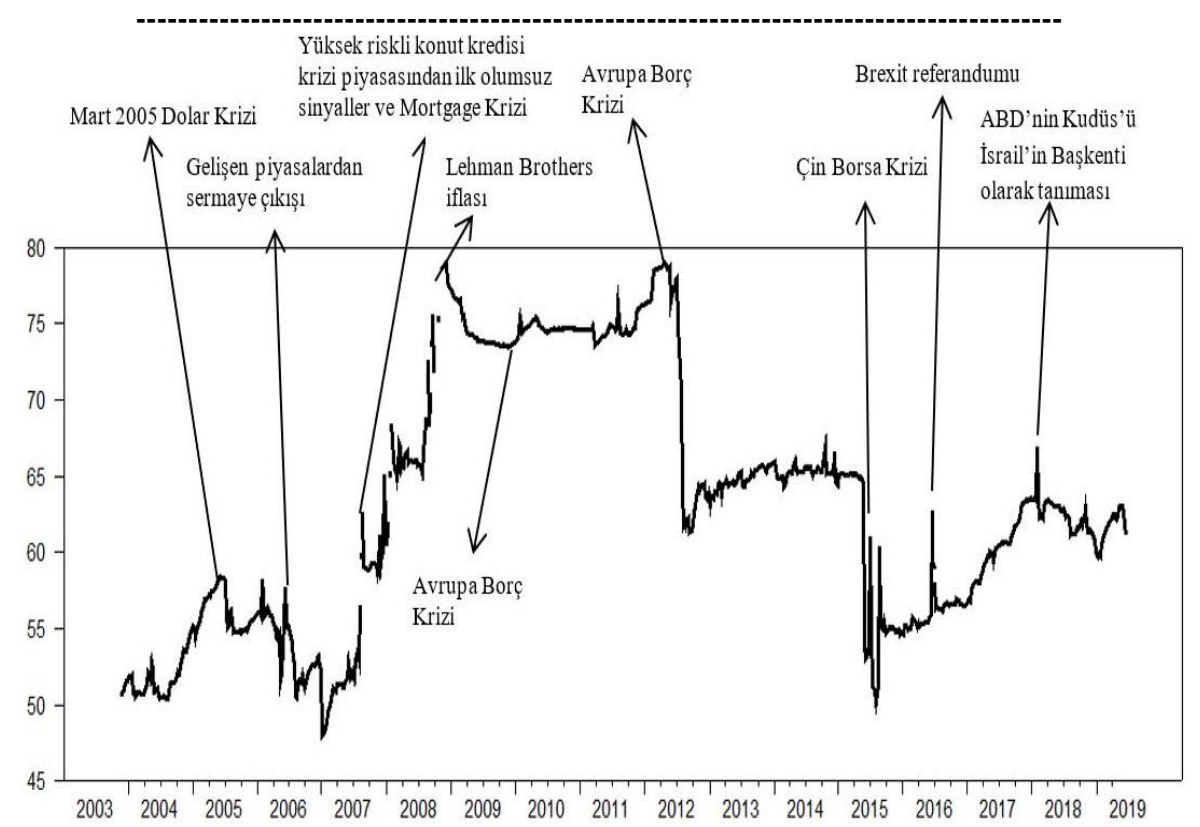

Şekil 2: Toplam Oynaklık Yayılımı 
2007 yılının sonuna yaklaşılırken yüksek riskli konut kredisi krizi piyasasından ilk olumsuz sinyaller gelmiş ve 2008 Mortgage Krizi patlak vererek toplam getiri yayılımının 2003-2017 dönemindeki en yüksek değerlerine ulaşmasına neden olmuştur. Avrupa borç krizi ${ }^{4}$, Suriye olayları ${ }^{5}$ ve Çin borsa krizi gibi olaylar da getiri yayılımının artmasına neden olmuştur. Çin borsa krizi ile hisse senetleri üç hafta içinde \% 30 değer kaybetmiş, yüzlerce firma anlaşmaları askıya almış ve çöküşün diğer pazarlara yayılmasından endişe edilmiştir. Brexit referandumundan sonra ve Manchester-Londra terör saldırılarının hemen ardından getiri yayılımı \%53 ile örneklemin en yüksek değerini almıştır. Sonuç olarak toplam getiri yayılımında ilki ABD ikincisi İngiltere kaynaklı şoklar neticesinde iki zirve yaşanmıştır.

Şekil 2 kayan pencere grafiğine göre toplam oynaklık yayılımı, toplam getiri yayılımı ile benzer olarak Mart 2005 Dolar Krizi ile yükselmiş ve bu süreç gelişen piyasalardan sermaye çıkışının yaşandığı dönemde de devam etmiştir ve hemen sonrasında düşüşe geçmiştir. Ancak yüksek riskli konut kredisi piyasasında 2017 yılının başından itibaren gelmeye başlayan kriz sinyalleri ve peşinden patlak veren 2008 küresel finansal kriz, toplam oynaklık yayılımının hızla artmasına neden olmuştur. Toplam oynaklık yayılımı 15 Ekim 2008'de Lehman Brother's iflası ile en yüksek değerine ulaşmış ve 2012 yılının ikinci çeyreğine kadar \%7580 aralığında seyretmiştir. Avrupa borç krizi ile tekrar \%80 düzeyine yaklaşan toplam yayılım, izleyen dönemde Çin borsa krizi, Brexit referandumu ve ABD’nin Kudüs'ü İsrail'in Başkenti olarak tanıması gibi olaylarla dönem dönem geçici olarak artış gösterse de kriz dönemine göre düşük düzeylerde seyretmiştir.

\section{SONUÇ}

Son yüzyılda küreselleşmenin artması birçok alanı etkilediği gibi finansal piyasaları ve bu piyasalar arasındaki entegrasyonu da önemli ölçüde etkilemiştir. Günümüzde, özellikle kriz dönemlerinde, finansal piyasalar ve ülke ekonomileri birbirlerinden etkilenmektedirler. Bunun sonucu olarak yatırımcılar için uluslararası portföy çeşitlendirmesi kararları daha fazla önem arz etmeye başlamıştır, çünkü piyasalar arasındaki entegrasyonun yüksek olması portföy çeşitlendirmesinin faydalarını azaltıcı bir etkiye sahiptir (Yarovaya vd., 2016). Bu bağlamda; "volatilite (oynaklık) yayılması" kavramı piyasa çalkantılarının bir ülkeden diğerine yayılmasını ifade eder (Dornbusch, vd., 2000).

Yapılan bu çalışmanın amacı gelişmiş ve gelişmekte olan piyasa ekonomilerinin yer aldığı 19 ülkeye ait hisse senedi endekslerinde oynaklık ve getiri yayılmalarının incelenmesidir. Çalışma, öncelikle Ocak 2000 ve Haziran 2019 olarak geniş dönemi kapsamakta ve bu dönemler arasındaki Mortgage krizi, Lehman Brothers'1n iflası, Avrupa borç krizi ve Brexit referandumu gibi önemli ekonomik ve politik olayları içermektedir. İkincisi, yapılan analizler Türkiye

\footnotetext{
${ }^{4}$ Kriz, Yunanistan'ın borçlarının temerrüde düşebileceğinin fark edilmesiyle başlamıştır. Üç yıl içinde, Portekiz, İtalya, İrlanda ve İspanya’ya ait borçlar temerrüt potansiyeline yükselmiştir. Kriz Almanya ve Fransa liderliğindeki Avrupa Birliği'nin bu üye ülkelere verdiği destek ile aşılabilmiştir.

${ }^{5}$ Şam'da gerçekleşen kimyasal saldırı sonucunda 1429 kişi hayatını kaybetmiştir. Olaylar ABD dışişleri bakanı John Kerry tarafından ahlaksızlık olarak nitelendirilmiş, ABD başkanı Barack Obama Esad rejimini saldırı ile tehdit etmiş ve İngiltere başbakanı David Cameron ABD'yi destekleyeceğini açıklamıştır.
} 
özelinde incelenmiş ve yorumlanmıştır. Bu çalışmanın gelişmekte olan önemli pazarlardan biri olan Türkiye'deki yayılma etkisi hakkında görüş vererek, literatüre katkıda bulunacağ düşünülmektedir.

Çalışmada Diebold ve Yılmaz (2009) yayılma endeksi yöntemi kullanılmış ve makro iktisadi değişkenler arasındaki şokların uluslararası yayılımı ölçülmüştür. Kullanılan bu yöntem ile ülkeler ve piyasalar arasındaki yayılım etkisi yüzdesel olarak elde edilebilmekte ve aynı zamanda yayılımın dinamik analizi yapılabilmektedir. Getiri ve oynalık yayılım bulguları değerlendirildiğinde, yayılımın en yüksek olduğu ülkelerin ABD ve İngiltere olduğu ve bu ülkelerin net finansal risk yayan ülkeler olduğu görülmektedir. Bu bulgular "ABD hapşırırsa dünya nezle olur" deyişini, yani sanayileşmiş ekonomilerin birer lokomotif görevi görerek dünya ekonomisine yön verdiklerini destekler niteliktedir. Elde edilen bulgular Türkiye özelinde incelendiğinde, Polat (2018)'ın da çalışmasında belirttiği gibi Türkiye'ye gelen ve Türkiye'den diğer ülkelere giden net yayılım etkisinin diğer ülkelere kıyasla yüksek seviyelerde olmadığı görülmektedir. Bu sonuca göre Türkiye ekonomisinin küresel şoklardan etkilenme düzeyinin yüksek olmadığını ve Türkiye'nin küresel ekonomiyi etkileyecek büyüklükte şoklar üretemediğini söylemek mümkündür. Bulgulara göre, Türkiye'de hisse senedi piyasası getirileri ve fiyat oynaklıkları çoğunlukla kendi iç şoklarından kaynaklanmaktadır. Ayrıca, toplam yayılımın zaman boyutundaki değişimi kayan örneklem (rolling-sample) analizi ile incelendiğinde; finansal stresin yüksek olduğu Mortgage krizi, Lehman Brothers iflası, Brexit referandumu gibi küresel olaylarda toplam yayılımın arttığ sonucuna ulaşılmıştır.

Bulgular, portföy yöneticileri ve kurumsal yatırımcılar gibi piyasa katılımcıları tarafından yatırım ve varlık tahsisi kararlarının değerlendirilmesinde önem arz etmektedir. Sonuçlara göre, küresel olayların Türkiye'ye yayılma etkisi az olduğundan, yatırımcılar bu tür dönemlerde risklerini azaltabilmek için portföylerini Borsa İstanbul' da yatırım yaparak çeşitlendirebilirler. Benzer şekilde, daha önce yaşanmış olan 2001 krizi gibi, yalnızca Türkiye'yi etkileyen olaylarda, Türkiye'den giden net yayılım etkisi yüksek olmadığından, yatırımcılar uluslararası portföy çeşitlendirmesi yoluna giderek Türkiye pazarından kaynaklı sistematik riskin etkisini azaltabilirler. Dolayısıyla, getiri ve oynaklık yayılımlarının yatırımcılar tarafından doğru bir şekilde incelenip yorumlanması portföy yönetimi açısından önemli bir yere sahiptir.

KAYNAKÇA

Akça, K. ve Öztürk, S.S. (2016) The Effect of 2008 Crisis on the Volatility Spillovers among Six Major Markets. International Review of Finance. 16 (1): 169-178.

Alfreedi, A.A. (2019) Shocks and Volatility Spillover Between Stock Markets of Developed Countries and GCC Stock Markets, Journal of Taibah University for Science. 13 (1): 112 120.

Bayramoğlu, M. F. ve Abasız, T. (2017). Gelişmekte Olan Piyasa Endeksleri Arasında Volatilite Yayılım Etkisinin Analizi. Muhasebe ve Finansman Dergisi. Nisan (2017): 183-200.

Beirne, J.; Caporale, G.M.; Schulze-Ghattas, M. ve Spagnolo, N. (2013). Volatility Spillovers and Contagion from Mature to Emerging Stock Markets. Review of International Economics. 21 (5): 1060-1075. 
Zeliha Can Ergün \& Can Karabıyı / Türkiye ve Dünya Hisse Senedi Piyasaları Arasındaki Getiri ve Oynaklık Yayılımlarının Ölçülmesi: Yayılma Endeksi Yaklaşımı

Büyükşalvarcı, A. (2010). Ekonomik Krizler ve Portföy Çeşitlendirmesi: İMKB Endeksleri Üzerine Faktör Analizi Uygulaması. Muhasebe ve Finansman Dergisi. (47): 229-243.

Chevallier, J., Dguyen, D.G., Siverskog, J. ve Uddin, G.S. (2018). Market Integration and Financial Linkages Among Stock Markets in Pacific Basin Countries. Journal of Empirical Finance. 46 (2018): 77-92.

Cronin, D. (2014). The interaction between money and asset markets: A spillover index approach. Journal of Macroeconomics. 39: 185-202.

Çelik, İ.; Özdemir, G. ve Gülbahar, S.D. (2018). Gelişmekte olan Ülkelerde Getiri ve Volatilite Yayılımı. Finans Politik ve Ekonomik Yorumlar. 55 (636): 9-24.

Demirgil, H. ve Gök, İ.Y. (2014). Türkiye ve Başlıca AB Piyasaları Arasında Asimetrik Volatilite Yayılımı. Yönetim ve Ekonomi Araştırmaları Dergisi. 23 (2014): 315-340.

Diebold, F.X. ve Y1lmaz, K. (2009). Measuring Financial Asset Return and Volatility Spillovers, with Application to to Global Equity Markets. The Economic Journal. 119 (January): 158-171.

Diebold, F. X., \& Yilmaz, K. (2012). Better to give than to receive: Predictive directional measurement of volatility spillovers. Special Section 1: The Predictability of Financial Markets. 28(1): 57-66. https://doi.org/10.1016/j.ijforecast.2011.02.006

Dornbusch, R., Park, Y. C. ve Claessens, S. (2000). Contagion: Understanding How It Spreads. The World Bank Research Observer. 15(2): 177-197.

Gallati, R. (2003). Risk Management and Capital Adequacy. US: McGraw-Hill.

Gamba-Santamaria, S., Gomez-Gonzalez, J. E., Hurtado-Guarin, J. L. ve Melo-Velandia, L. F. (2017). Stock Market Volatility Spillovers: Evidence for Latin America. Finance Research Letters. 20: 207-216.

Gamba-Santamaria, S., Gomez-Gonzalez, J. E., Hurtado-Guarin, J. L. ve Melo-Velandia, L. F. (2019). Volatility Spillovers among Global Stock Markets: Measuring Total and Directional Effects. Empirical Economics. 56(5): 1581-1599.

Garman, M. B., \& Klass, M. J. (1980). On the Estimation of Security Price Volatilities from Historical Data. The Journal of Business. 53(1): 67-78. JSTOR.

Gökbulut, R. İ. (2017). An Empirical Analysis of Volatility Transmission Between BIST and International Stock Markets. Ekonomik ve Sosyal Araştırmalar Dergisi. 13 (1): 141-159.

Hung, N.T. (2019). Return and volatility spillover across equity markets between China and Southeast Asian countries. Journal of Economics, Finance and Administrative Science. 24 (47): 6681.

Kırkulak Uludağ, B. ve Ezzat, H. (2017). Volatility Spillover Effect in MENA Stock Markets: Evidence from Pre-and Post- Egyptian Revolution. Journal of Yasar University. 12 (45): $32-47$.

Longin, F. ve Solnik, B. (2001). Extreme Correlation of International Equity Markets. The Journal of Finance. 56(2): 649-676.

Markowitz, H. (1952). Portfolio Selection. The Journal of Finance. 7 (1): 77-91.

Özdemir, L. ve Vurur, S. (2019), "Volatility Spillovers Between BIST100 Index and S\&P500 Index", Grima, S., Özen, E., Boz, H., Spiteri, J. ve Thalassinos, E. (Ed.) Contemporary Issues in Behavioral Finance (Contemporary Studies in Economic and Financial Analysis, Vol. 101), Emerald Publishing Limited, pp. 29-43.

Polat, O. (2018). Hisse Senedi Piyasalarında Finansal Bağlantılılık Analizi. Politik Ekonomik Kuram, 2(1), 73-86.

Sahar, N. ve Shah, S.Z.A. (2017). Stock Market Return and Volatility Spillovers: The Case of Selected Muslim Majority Countries. Journal of Islamic Business and Management. 7 (1): 68-86.

Sujan, N. ve Govil, M. (2013). International Diversification - Can It Reduce Systematic Risk? QuestJournal of Management and Research. 3(2): 81-92.

Taşdemir, M. ve Yalaman, A. (2010). Inter-Regional Volatility Spillovers Between Emerging Capital Markets: Evidence from Turkey and Brazil. Turkish Economic Association. Discussion Paper.

2010/8. https://www.researchgate.net/publication/254451592_InterRegional_Volatility_Spillovers _Between_Emerging_Capital_Markets_Evidence_From_Turkey_And_Brazil (accessed: 10.12.2019) 
Tsai, I.C. (2014). Spillover of Fear: Evidence from the Stock Markets of Five Developed Countries. International Review of Financial Analysis. 33 (2014): 281-288.

Yarovaya, L.; Brzeszczyński, J. ve Lau, C.K.M. (2016). Intra- and inter-regional return and volatility spillovers across emerging and developed markets: Evidence from stock indices and stock index futures. International Review of Financial Analysis. 43 (2016): 96-114.

Zhou, X., Zhang, W., \& Zhang, J. (2012). Volatility spillovers between the Chinese and world equity markets. Pacific-Basin Finance Journal. 20(2): 247-270.

\section{SUMMARY}

In the last decade, the rise of the globalization has affected the financial markets and the integration between those markets. Especially during the economic crisis periods, financial markets and economies of different countries influence each other. For instance; 1997 Asian crisis had started in Asian countries, then it had spread to Russia and followingly the crisis overspread to other countries. Similarly, 2008 global financial crisis initially had started in the US, and it affected many developing and developed economies later on. From these examples, the effect of globalization could be observed apparently. Consequently, because of the high integration between financial market; the benefits of portfolio diversification could decrease. Therefore, today, the international portfolio diversification decisions have become more important for investors. In this context; the concept of "volatility spillover" refers to the spread of market turbulence from one country to another.

In light of the above explanations, the aim of this study to examine the volatility and return spillover effect in the stock indices of 19 developed and developing market economies during the period between January 2000 and June 2019 , and it is also aimed to examine the findings specifically for Turkish stock exchange market (Borsa Istanbul). This study covers the broad period and includes important economic and political events such as the Mortgage crisis, the bankruptcy of Lehman Brothers, the European debt crisis and the Brexit referendum. This study is believed to contribute to the literature by giving opinions about the spillover effect in Turkey which is one of the most important emerging markets in the world. In the study, the spillover index method of Diebold and Yilmaz (2019) is used and the international spillover of shocks between macroeconomic variables has been measured. With this method, the spillover effect between countries and markets can be obtained as a percentage and dynamic analysis of the spillover can be done at the same time.

When the return and volatility spillover findings in Table 3 are evaluated, it is seen that the US and the UK own the highest spillover effect among other countries and these two economies spread net financial risk to others. These findings support "if the USA sneezes, the world catches cold" argument. In other words, it could be expressed that the industrialized economies are leading the world economy by acting as locomotives. If the findings are examined specifically for Turkey, it could be stated that when it is compared to other countries the net spillover effect seems at not their high levels from Turkey to other countries and vice versa. According to this result, the influence of global shocks on Turkish 
economy is not very high and also Turkey cannot produce shocks which are large enough to affect the global economy. The findings show that the return and the price volatility of Borsa Istanbul stem mainly from its internal shocks. In addition, the variation in the time dimension of the total spillover is analyzed by rollingsample analysis, and it is found that the total spillover has increased during crucial global events where financial stress is high such as Mortgage crisis, Lehman Brothers bankruptcy and Brexit referendum.

The findings are important in evaluating investment and asset allocation decisions by market participants such as portfolio managers and institutional investors. According to the results, since the spillover effect of the global events to Turkey is low, investors can diversify their portfolios by investing in the Borsa Istanbul in order to reduce the risks of such period. Similarly, since the outgoing net spillover effect is not high from Borsa Istanbul to other stock exchanges, in cases affecting only Turkey investors can reduce systemic risks that is sourced from Turkey by international portfolio diversification. Therefore, the accurate analysis and interpretation of returns and volatility spillovers has an important place in terms of portfolio management. 